\title{
STRATEGI PENINGKATAN INVESTASI KABUPATEN INDRAMAYU
}

\author{
Investments Increasing Strategy of Indramayu Regency
}

\author{
Komadin 1, Sri Hartoyo 2, dan Dedi Budiman Hakim ${ }^{2}$ \\ 1 Staff PT Bangun Bumi Bersatu. E-mail: dinkomadin@gmail.com \\ 2 Staff Pengajar Departemen Ilmu Ekonomi. Fakultas Ekonomi dan Manajemen IPB \\ E-mail: shty@indo.net.id, dedihakim@gmail.com.
}

\begin{abstract}
Indramayu is regency that produce Oil and Earth Gas in Indonesian and as main paddy granary for West Java Province. So that the investment in this sectors is a strategic effort. Region development study have intention to know investment developing, analyzing investment competitiveness and make Indramayu Regency investment increasing strategy. Methods that is used in this study is competitiveness analysis by using SWOT (Strength, Weakness, Opportunity and Threats) and AHP (Analytical Hierarchy Process) method. The Analysis showing result: First, Indramayu Regency up to year 2000-2005 experience investment decreases. Second, analysis result about investment competitiveness show the priorities factor that most regard Indramayu Regency investment competitiveness alternately which ares strength factor $(0,458)$, weakness $(0,280)$, opportunity $(0,162)$, and threat (0,100). Third, from the competitiveness analysis, priority alternative strategy in increasing Indramayu Regency investment alternately which are developing zone and industrial cluster (0,551), developing agroindustry upstream until downstream (0,237), developing institution $(0,138)$, and increasing human capital quality (0,074).
\end{abstract}

Keywords: Indramayu, Competitiveness, Investment Increasing Strategy

\begin{abstract}
ABSTRAK
Indramayu merupakan kabupaten yang memproduksi minyak dan gas bumi di Indonesia dan sebagai lumbung padi utama untuk Provinsi Jawa Barat. Sehingga invetasi di sektor tersebut merupakan sebuah upaya strategis. Kajian pembangunan daerah ini bertujuan untuk mengetahui perkembangan investasi, menganalisa daya saing investasi dan membuat strategi peningkatan investasi Kabupaten Indramayu. Metode yang digunakan dalam kajian ini adalah analisis menggunakan metode SWOT (Strength, Weekness, Oportunity, dan Threath) dan AHP (Analitycal Hierarchi Process). Hasil nnalisis menunjukan bahwa: Pertama, Kabupaten Indramayu mengalami penurunan investasi selama 2000-2005. Kedua, hasil analisis mengenai daya saing investasi menunjukkan faktor prioritas yang paling terkait dengan daya saing investasi Kabupaten Indramayu, yaitu: faktor kekuatan $(0,458)$, kelemahan $(0,280)$, peluang $(0,162)$, and ancaman $(0,100)$. Ketiga dari analisis daya saing tersebut Prioritas alternatif strategi dalam peningkatan investasi Kabupaten Indramayu secara berurutan yaitu mengembangkan zona dan kluster industri $(0,551)$, mengembangkan agroindustry hulu sampai hilir $(0,237)$, mengembangkan kelembagaan pelayanan perizinan dan investasi $(0,138)$, dan meningkatkan kualitas sumber daya manusia $(0,074)$.
\end{abstract}

Kata kunci: Indramayu, Daya Saing, Strategi Peningkatan Investasi

\section{PENDAHULUAN}

\section{Latar Belakang}

Pertumbuhan ekonomi selalu diikuti oleh perubahan dalam struktur, corak kegiatan ekonomi dan semakin kecilnya ketimpangan pendapatan antar penduduk antar daerah dan antar sektor (Kuncoro, 2004). Investasi bertujuan menciptakan pertumbuhan ekonomi yang setinggi-tingginya serta bertujuan menghapus atau mengurangi tingkat kemiskinan, ketimpangan pendapatan, dan tingkat pengangguran. Pembangunan ekonomi daerah adalah suatu proses dimana pemerintah daerah dan masyarakatnya mengelola sumber daya yang ada dan membentuk suatu pola kemitraan antara pemerintah daerah dengan sektor swasta untuk menciptakan suatu lapangan kerja baru dan merangsang 
perkembangan kegiatan ekonomi (pertumbuhan ekonomi) dalam wilayah tersebut (Arsyad, 1999).

Berdasarkan

kebijakan

pengembangan Rencana Tata Ruang Wilayah (RTRW) Provinsi Jawa Barat, Kabupaten Indramayu wilayah timur merupakan wilayah utama yang berfungsi sebagai motor penggerak utama kegiatan perekonomian Jawa Barat bagian timur (Badan Perencanaan Daerah Kabupaten Indramayu, 2005). Kegiatan utama wilayah ini memiliki keterkaitan yang kuat dengan sistem perekonomian interregional dan intraregional yaitu kegiatan ekonomi industri, perdagangan dan jasa, pemukiman, dan pertanian lahan basah.

Investasi adalah salah satu faktor penting penentu keberhasilan pembangunan ekonomi. Keberadaan investasi merupakan modal dasar bagi perwujudan pertumbuhan ekonomi yang berkelanjutan. Investasi akan meningkatkan penawaran melalui peningkatan stok kapital yang pada gilirannya akan meningkatkan sektor produksi untuk menghasilkan output atau melakukan kegiatan-kegiatan produksi (Bappenas, 2007). Kegiatan produksi tersebut akan meningkatkan penyerapan tenaga kerja dan proses tersebut pada akhirnya meningkatkan kualitas pembangunan ekonomi.

Meningkatnya intensitas perekonomian akan membuka peluang kerja penduduk di daerah sekitar penanaman modal investasi. Sehingga, secara langsung dan tidak langsung akan terwujud multiplier effect terhadap kegiatan ekonomi dan pendapatan penduduk di kawasan-kawasan sekitar dan pada gilirannya akan meningkatkan pendapatan daerah secara keseluruhan. Lingkaran ekonomi ini akan semakin besar dengan munculnya investasi pada potensipotensi baru dalam membangun sektor industri lainnya.

Dalam konteks pembangunan

2 Indramayu, kepentingan peningkatan investasi sesungguhnya memiliki tujuan yang lebih luas daripada hanya sebagai penciptaan pertumbuhan ekonomi secara berkelanjutan. Misi peningkatan investasi pada dasarnya mencakup tiga tujuan yang saling berkaitan, yaitu: (1) penciptaan pertumbuhan ekonomi dan kesempatan lapangan kerja, (2) berkurangnya jumlah penduduk miskin, dan (3) terwujudnya kesejahteraan masyarakat yang berkelanjutan (Pemerintah Daerah Kabupaten Indramayu, 2006).

\section{Perumusan Masalah}

Menurut Dinas Perizinan dan Penanaman Modal Daerah (DPPMD) Kabupaten Indramayu (2007) dan Badan Promosi dan Penanaman Modal Daerah (BPPMD) Jawa Barat (2006), perkembangan realisasi investasi selama periode tahun 2000-2005 sebanyak 14 proyek dengan nilai investasi sebesar Rp 301.170.354.401, meliputi PMDN sebanyak empat proyek dengan nilai investasi $\mathrm{Rp}$ 125.457.596.901, PMA sebanyak sembilan proyek dengan nilai investasi USD 20.491.000, dan Non PMA/PMDN satu proyek dengan nilai investasi Rp 50.000.000.000. Bidang usaha yang banyak diminati dalam investasi adalah industri pengolahan minyak dan gas serta pertanian secara luas.

Bidang usaha yang diminati investor tersebut berdampak terhadap perkembangan perekonomian Kabupaten Indramayu. PDRB Kabupaten Indramayu didominasi oleh sektor industri pengolahan minyak dan gas dan sektor pertanian secara luas. Sektor industri pengolahan kontribusinya sebesar 56 persen dan sektor pertanian sebesar 16 persen. Peranan sektor industri pengolahan minyak dan gas serta sektor pertanian menjadi sangat penting bahkan sektor-sektor ini sebagai lokomotif dan penggerak roda perekonomian Kabupaten Indramayu (BPS Kabupaten Indramayu, 2005).

Dilihat dari perkembangan investasi di Indramayu, baik PMA, PMDN dan Non PMA/PMDN selalu mengalami turun naik dalam setiap tahunnya, berdasarkan pemeringkatan investasi 
Badan Promosi dan Penanaman Modal Daerah (BPPMD) Provinsi Jawa Barat, selama tahun 2000-2005. Investasi di Indramayu menempati urutan 15 dari 25 Kabupaten dan Kota dengan 13 jumlah proyek, PMA dengan sembilan proyek dan PMDN dengan empat proyek (BPPMD, 2006). Hal ini mengindikasikan daya tarik investasi Kabupaten Indramayu tidak begitu baik dibandingkan dengan daerah lainnya.

Upaya peningkatan investasi sangat terkait erat dengan upaya peningkatan daya saing investasi daerah. Dalam kaitan inilah, diperlukan strategi untuk mengintegrasikan berbagai kepentingan dan upaya memobilisasi para pelaku, organisasi, dan sumberdaya. Dengan demikian, pertanyaan utama kajian ini adalah bagaimana kebijakan strategi peningkatan investasi di Kabupaten Indramayu.

\section{Tujuan Penelitian}

Tujuan umum kajian ini adalah untuk merumuskan kebijakan strategi peningkatan investasi di Kabupaten Indramayu. Untuk memenuhi tujuan umum tersebut, maka tujuan spesifik dari kajian ini adalah:
1. Menganalisis perkembangan investasi di Kabupaten Indramayu.

2. Mengidentifikasi dan menganalisis faktor-faktor yang mempengaruhi investasi di Kabupaten Indramayu.

3. Merumuskan kebijakan strategi dan program peningkatan investasi di Kabupaten Indramayu.

\section{TINJAUAN PUSTAKA}

\section{Peranan Investasi Dalam Pembangunan}

Investasi mengandung arti setiap kegiatan yang meningkatkan kemampuan ekonomi untuk memproduksi output dimasa yang akan datang. Dalam hal ini investasi tidak hanya berupa penambahan persediaan fisik modal tetapi juga menyangkut investasi sumberdaya manusia. Menurut Levina dan Renelt (1992) investasi merupakan faktor yang esensial dalam proses pertumbuhan ekonomi, adanya investasi akan mendorong peningkatan modal pertenaga kerja (per kapita). Adanya arus investasi akan mempercepat pertumbuhan ekonomi melalui transfer modal, teknologi, manajemen dan kewirausahaan. Untuk dapat secara terus menarik minat investor berinvestasi, maka upaya-upaya perbaikan daya saing investasi harus ditingkatkan.

Tabel 1. Indikator Ekonomi Kabupaten Indramayu 2000-2006

\begin{tabular}{lccccccc}
\hline \multicolumn{1}{c}{ Indikator } & 2000 & 2001 & 2002 & 2003 & 2004 & 2005 & 2006 \\
\hline $\begin{array}{l}\text { PDRB Atas Dasar Harga } \\
\text { Berlaku (Trilyun) }\end{array}$ & 12.943 & 14.159 & 16.713 & 17.575 & 19.898 & 23.590 & 31.896 \\
$\begin{array}{l}\text { PDRB Atas Dasar Harga } \\
\text { Konstan (Trilyun) }\end{array}$ & 12.943 & 12.913 & 13.812 & 12.775 & 13.369 & 12.323 & 12.621 \\
$\begin{array}{l}\text { Laju Pertumbuhan PDRB } \\
\text { Atas Dasar Harga Berlaku }\end{array}$ & - & 9.40 & 18.03 & 5.16 & 13.22 & 18.56 & 35.20 \\
Laju Pertumbuhan PDRB & - & -0.23 & 6.96 & -7.51 & 4.65 & -7.82 & 2.42 \\
$\begin{array}{l}\text { Atas Dasar Harga Konstan } \\
\text { Inflasi PDRB Penggunaan }\end{array}$ & - & 9.65 & 10.35 & 13.69 & 8.19 & 28.62 & 32.01 \\
\hline
\end{tabular}

Sumber: BPS Kabupaten Indramayu, 2007

Pertumbuhan ekonomi Kabupaten Indramayu menurut PDRB atas dasar harga berlaku dan harga konstan tahun 2000 menunjukan terjadinya kenaikan dan penurunan yang relatif tajam bahkan terjadi laju pertumbuhan negatif. Kenaikan PDRB harga berlaku terus naik karena besarnya kontribusi sektor Migas sedangkan menurunnya pertumbuhan PDRB harga konstan adalah karena kontribusi sektor lainnya tidak berkembang sekaligus dibarengi dengan koreksi oleh inflasi yang tinggi sebagaimana dalam Tabel 1. 
Tabel 2. PDRB Kabupaten Indramayu 2000-2006 Atas Dasar Harga Konstan 2000 (dalam Triliun Rupiah)

\begin{tabular}{|c|c|c|c|c|c|c|c|c|}
\hline \multicolumn{2}{|c|}{ Indikator } & 2000 & 2001 & 2002 & 2003 & 2004 & 2005 & 2006 \\
\hline Pengeluaran & Konsumsi & 5.491 & 5.629 & 5.647 & 5.493 & 5.828 & 6.734 & 6.870 \\
\hline $\begin{array}{l}\text { Rumah Tangga } \\
\text { Pengeluaran } \\
\text { Lembaga Non P }\end{array}$ & $\begin{array}{l}\text { Konsumsi } \\
\text { rofit }\end{array}$ & 0.017 & 0.017 & 0.020 & 0.020 & 0.021 & 0.021 & 0.023 \\
\hline $\begin{array}{l}\text { Pengeluaran } \\
\text { Pemerintah }\end{array}$ & Konsumsi & 0.086 & 0.208 & 0.233 & 0.229 & 0.362 & 0.255 & 0.371 \\
\hline $\begin{array}{l}\text { Pembentukan } \\
\text { Tetap Bruto }\end{array}$ & Modal & 3.631 & 3.508 & 3.590 & 3.593 & 3.638 & 3.696 & 3.702 \\
\hline Perubahan Stok & & 0.538 & 0.470 & 0.550 & 0.493 & 0.563 & 0.502 & 0.511 \\
\hline Ekspor Netto & & 3.180 & 3.082 & 3.774 & 2.948 & 2.958 & 1.115 & 1.144 \\
\hline PDRB & & 12.943 & 12.913 & 13.812 & 12.775 & 13.369 & 12.323 & 12.621 \\
\hline
\end{tabular}

Sumber: BPS Kabupaten Indramayu, 2007

Selanjutnya Tabel 2 menunjukan bahwa pertumbuhan ekonomi Kabupaten Indramayu saat ini sebagian besar bersumber dari peningkatan konsumsi rumah tangga. Pertumbuhan ekonomi daerah yang didorong oleh konsumsi sulit dijaga keberlangsungan dan kestabilannya. Pertumbuhan ekonomi daerah seperti itu tidak menunjukkan struktur perekonomian daerah yang kuat. Selain itu, pertumbuhan ekonomi yang mengandalkan konsumsi tidak akan mempunyai dampak kedepan pada pertumbuhan ekonomi malah memicu peningkatan inflasi.

Dampak pengganda yang diciptakan dari peningkatan investasi adalah meningkatnya pemanfaatan sumberdaya secara optimal dalam kegiatan produksi, berkembangnya kegiatan perdagangan antar daerah, dan terciptanya nilai tambah yang lebih besar. Investasi dapat menjadi pendorong roda perekonomian daerah dan meningkatkan kesejahteraan ketika semua pihak mendapat manfaat maksimal dari aktivitas tersebut (Bappenas, 2007). Selanjutnya menurut BKPM (1994) Ada tiga aspek peranan investasi dalam pembangunan daerah yaitu 1) aspek ekonomi makro, 2) aspek penyediaan lapangan kerja, dan 3) aspek bisnis.

Noor (2005) mengelompokan investasi menjadi dua yaitu (1) investasi langsung (direct investment) dan (2) investasi tidak langsung (indirect investment). Investasi langsung pada dasarnya investasi pada aset atau faktor produksi untuk melakukan usaha (bisnis), investasi jenis ini lebih terkenal sebagai investasi sektor riil, misalnya perkebunan, peternakan, pabrik, toko dan jenis usaha lainnya. Investasi langsung ini menghasilkan dampak berganda (multiplier effect) yang besar terhadap masyarakat luas. Investasi tidak langsung adalah investasi pada asset keuangan (financial asset) seperti deposito, surat berharga seperti pada saham dan obligasi, commercial paper, reksadana dan sebagainya.

Menurut BKPM (2007), berdasarkan sumber modalnya, penanaman modal atau investasi terdiri dari (1) Penanaman Modal Asing (PMA), adalah kegiatan menanam modal untuk melakukan kegiatan usaha di wilayah negara Indonesia yang dilakukan oleh penanam modal asing, baik yang menggunakan modal asing sepenuhnya maupun berpatungan dengan penanam modal dalam negeri, dan (2) Penanaman Modal Dalam Negeri (PMDN), adalah kegaiatan menanam modal untuk melakukan usaha di wilayah negara Indonesia yang dilakukan oleh penanam modal dalam negeri. 


\section{Hubungan Investasi dengan Perekonomian Daerah}

Investasi adalah kata kunci penentu laju pertumbuhan ekonomi, karena disamping akan mendorong kenaikan output secara signifikan juga secara otomatis akan meningkatkan permintaan input, sehingga pada gilirannya akan meningkatkan kesempatan kerja dan kesejahteraan masyarakat sebagai konsekuensi dari meningkatnya pendapatan yang diterima masyarakat (Levina dan Renelt, 1992).

Menurut Soekirno (1994) investasi yang diinginkan adalah investasi yang besarnya dipengaruhi oleh pendapatan nasional atau pertambahan permintaan efektif. Dengan demikian dilihat dari penggolongan jenis investasi diatas untuk investasi yang diinginkan (induced investment) ditinjau dari sektor pemerintahan, besarnya investasi tersebut dipengaruhi oleh besarnya jumlah GDP atau perubahannya dalam skala nasional, atau besarnya GDP atau GDP per kapita pada tingkat daerah.

Hal ini berarti pertumbuhan ekonomi dapat diartikan sebagai kenaikan GDP/GNP tanpa memandang apakah kenaikan itu lebih besar atau kecil dari tingkat pertumbuhan penduduk, apakah perubahan struktur ekonomi terjadi atau tidak (Arsyad, 1999). Menurut Boediono (1985), pertumbuhan ekonomi adalah proses kenaikan output per kapita dalam jangka panjang. Disini proses mendapat penekanan karena mengandung unsur dinamis.

\section{Kerangka Pemikiran}

Kerangka pemikiran dari strategi peningkatan investasi Kabupaten Indramayu, didasari pada visi dan misi Kabupaten Indramayu 2006 yang bertujuan terciptanya pertumbuhan ekonomi yang optimal dengan memanfaatkan potensi ekonomi yang tersedia.

Adapun langkah-langkah kerangka dasar strategi peningkatan investasi, yaitu: Pertama, dengan menggunakan konsep pengukuran daya saing daerah oleh Bank Indonesia (Boediono, et.al, 2004). konsep daya saing daerah diartikan sebagai kemampuan perekonomian daerah dalam meningkatkan kesejahteraan yang tinggi dan berkelanjutan dengan tetap terbuka pada persaingan domestik dan internasional. Dengan mengacu pada pengertian tersebut, pengukuran daya saing daerah menggunakan sembilan indikator utama, yaitu:

1. Perekonomian daerah,

2. Keterbukaan,

3. Sistem keuangan,

4. Infrastruktur dan sumberdaya alam,

5. Ilmu pengetahuan dan teknologi,

6. Sumberdaya manusia,

7. Kelembagaan,

8. Kebijakan pemerintah, dan

9. Manajemen dan ekonomi mikro.

Kedua, penelitian ini menggunakan analisis AWOT yang merupakan gabungan dari metode SWOT (Rangkuti, 2004) dengan AHP (Saaty, 1993). Penentuan setiap komponen SWOT diperoleh dari hasil wawancara dengan responden dan penentuan alternatif strategi pengembangan ekonomi sektor unggulan dan sektor potensial merupakan data sekunder hasil kajian Location Quotation (LQ) dan Input Output (I-O). Analisis SWOT menyediakan kerangka dasar yang akan menghasilkan faktor-faktor internal dan ekternal yang mempengaruhi kondisi investasi di Kabupaten Indramayu. Setelah data-data SWOT didapatkan maka dilakukan analisis AHP untuk membuat prioritas strategi alternatif peningkatan investasi di Indramayu.

Dengan demikian agar terjadinya peningkatan investasi di Kabupaten Indramayu diperlukan perencanaan daya saing investasi yang didalamnya mencakup visi, misi, strategi dasar, pelaku-pelaku investasi baik swasta maupun pemerintah dan analisis faktor-faktor peningkatan daya saing investasi dan prioritas strategi alternatif untuk itu maka diperlukan tahapan penelitian yang dapat dilihat pada Gambar 1. 


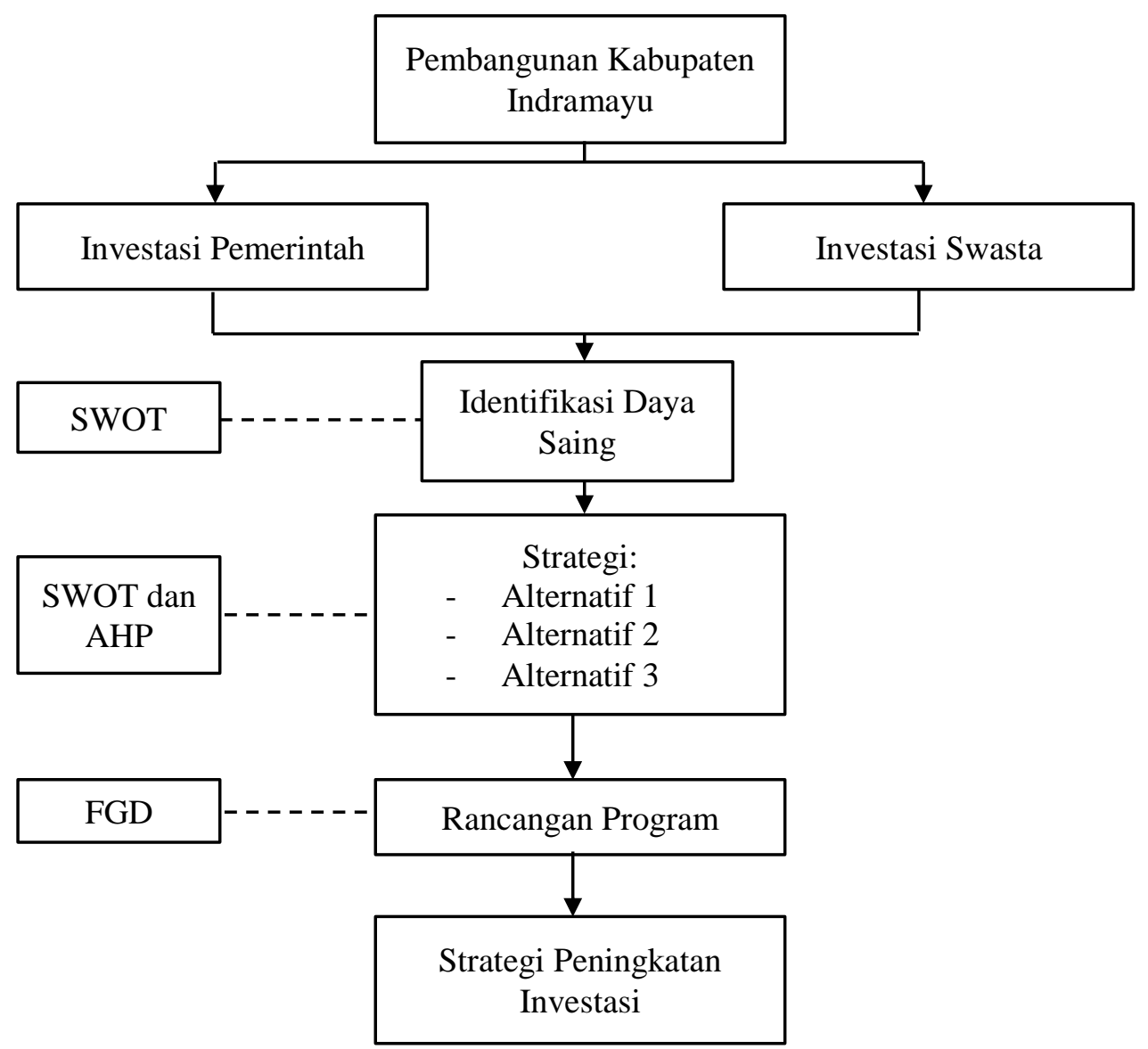

Gambar 1. Kerangka Pemikiran Penelitian

\section{METODE PENELITIAN}

\section{Lokasi dan Waktu Penelitian}

Penelitian dilakukan di Kabupaten Indramayu. Dasar pemikiran dipilihnya daerah ini karena Kabupaten Indramayu merupakan daerah penghasil minyak bumi dan gas (migas) dengan kurang lebih 20 persen dari total produksi migas nasional, selain itu merupakan daerah andalan pertanian penghasil padi di Jawa Barat. Kedua potensi ini memiliki kontribusi ekonomi yang relatif tinggi terhadap pembentukan PDRB Provinsi Jawa Barat sebesar 7,35 persen pada tahun 2006 (BPS, 2007). Penelitian lapangan dilakukan pada bulan September 2007 - Januari 2008.

\section{Jenis dan Sumber Data}

Penelitian pembangunan daerah ini menggunakan data primer dan data skunder. Data primer berupa data mengenai daya saing investasi serta penentuan prioritas strategi peningkatan investasi di Kabupaten Indramayu diperoleh melalui mekanisme survei, wawancara, dan Focus Group Discution (FGD) yang melibatkan beberapa informan dibidangnya masing-masing. Para informan terdiri dari Asisten Daerah Bidang Pemerintahan, Kasubid Pengembangan Dunia Usaha Badan Perencanaan Daerah, Kepala Dinas dan Seksi Perizinan Dinas Perizinan dan Penanaman Modal, Kepala Seksi Neraca dan Analisis Statistik BPS, Direktur Teknik PT Greenworld Energy Nusantara, dan Direktur Pengembangan PT Bakti Mingas Utama. Data sekunder berupa data kualitatif terdiri atas perkembangan investasi, potensi ekonomi, keuangan daerah, dan sumber daya manusia dan peraturan daerah. Data ini diperoleh dari Kantor Perijinan dan Penanaman Modal, Badan Perencanaan Pembangunan Daerah, BPS, dan instansi lainnya. 


\section{Metode Analisis}

Setelah data yang terkait dengan kajian diperoleh maka data tersebut diolah, sehingga dapat digunakan sebagai bahan untuk menentukan strategi peningkatan investasi Kabupaten Indramayu. Alat analisa yang digunakan pada kajian ini dengan menggunakan analisa daya saing dan analisa SWOT dan AHP.

Tabel 3. Analisis Kajian, Jenis Data, Sumber Data, dan Metode Analisis

\begin{tabular}{|c|c|c|c|}
\hline Tujuan & Jenis Data & Sumber Data & Metode Analisis \\
\hline $\begin{array}{l}\text { Menganalisis investasi di } \\
\text { Kabupaten Indramayu }\end{array}$ & $\begin{array}{l}\text { Jumlah proyek, nilai } \\
\text { investasi, bidang usaha dan } \\
\text { pelaku PMDN dan PMA }\end{array}$ & $\begin{array}{l}\text { Kantor Perizinan dan } \\
\text { Penanaman Modal } \\
\text { Kabupaten Indramayu }\end{array}$ & Deskriptif \\
\hline $\begin{array}{l}\text { Identifikasi dan analisa } \\
\text { faktor daya saing } \\
\text { investasi Indramayu }\end{array}$ & $\begin{array}{l}\text { - Kekuatan } \\
\text { - Kelemahan } \\
\text { - Peluang } \\
\text { - Ancaman }\end{array}$ & Wawancara Expertis & $\begin{array}{l}\text { - SWOT } \\
\text { - AHP }\end{array}$ \\
\hline $\begin{array}{l}\text { Menentukan strategi dan } \\
\text { program peningkatan } \\
\text { investasi }\end{array}$ & $\begin{array}{l}\text { Hasil analisis SWOT - } \\
\text { AHP }\end{array}$ & Responden & $\begin{array}{l}\text { Focus Group } \\
\text { Discussion }\end{array}$ \\
\hline
\end{tabular}

\section{HASIL DAN PEMBAHASAN}

\section{Perkembangan Investasi Swasta di Kabupaten Indramayu}

Data perkembangan investasi sampai dengan periode September 2007 menurut Dinas Perizinan dan Penanaman Modal Kabupaten Indramayu (2007) meliputi (1) PMDN sebanyak empat perusahaan dengan investasi Rp 125.457.596.901, (2) PMA sebanyak sembilan perusahaan dengan nilai investasi sebesar USD 20.491.000, dan (3) Non PMA/PMDN satu perusahaan dengan nilai investasi Rp 50.000.000.000.

Bidang usaha yang banyak diminati adalah industri yang mengolah minyak dan gas serta pertanian secara luas dan pengolahannya. Bidang usaha yang diminati investor tersebut sangat signifikan dengan perkembangan perekonomian Kabupaten Indramayu yang PDRB-nya didominasi oleh sektor industri pengolahan minyak dan gas dan sektor pertanian. Sektor industri pengolahan kontribusinya sebesar 56 persen dan sektor pertanian sebesar 16 persen. (BPS, 2005). Peranan sektor industri pengolahan minyak dan gas dan pertanian menjadi sangat penting bahkan sektor-sektor ini sebagai lokomotif dan penggerak roda perekonomian Kabupaten Indramayu.
Jumlah industri besar dan sedang di Indramayu hingga Tahun 2005 mencapai 35 unit usaha dengan 10 jenis industri. Jumlah tenaga kerja paling banyak pada jenis industri kimia organik dengan jumlah sebanyak 785 tenaga kerja, kemudian industri kerupuk ikan dan udang sebanyak 300 tenaga kerja, dan diikuti berturut-turut oleh industri waterglass, rajungan, es batu, keramik lantai, teri nasi, logam, kimia $\mathrm{CO} 2$, dan kayu putih.

\section{Perkembangan Investasi Pemerintah di Kabupaten Indramayu}

Pembangunan di Kabupaten Indramayu diprioritaskan pada tiga bidang pembangunan, yaitu pendidikan, kesehatan, dan pembangunan infrastruktur. Dengan demikian alokasi pengeluaran pembangunan pada APBD Kabupaten Indramayu yang terbesar adalah pada bidang infrastruktur seperti pembangunan jalan, jembatan, pembangunan gedung sekolah, rumah sakit, dan lain-lain.

Untuk mengukur dampak dari alokasi pembangunan terhadap pertumbuhan ekonomi, dapat dikaji dengan menghubungkan antara pendapatan regional (PDRB) dan investasi pemerintah dimana dalam teori pembangunan diketahui bahwa tingkat pertumbuhan ekonomi dan investasi mempunyai hubungan timbal balik yang positif. Semakin tinggi pertumbuhan ekonomi 
suatu negara, berarti semakin besar bagian dari pendapatan yang bisa ditabung sehingga investasi yang tercipta akan semakin besar pula. Hal ini berarti investasi merupakan fungsi dari pertumbuhan ekonomi. Di lain pihak semakin besar investasi suatu negara akan semakin besar pula tingkat pertumbuhan ekonomi yang bisa dicapai. Dengan demikian pertumbuhan merupakan fungsi investasi.

Dana untuk infrastruktur listrik, irigasi, perbaikan jalan raya, pendidikan dan kesehatan selalu turun naik antara 26 persen sampai 30 persen. Berbeda dengan belanja administrasi umum mendapatkan proporsi yang besar diatas 60 persen dan belanja langsung sekitar 20 persen. Ini berarti sebagian besar dana dialokasikan untuk belanja rutin yang tidak terkait dengan kinerja dan lebih pada berhubungan keperluan birokrasi. Akibat dari belanja langsung yang terkait dengan kinerja penyelenggaraan pemerintah dan penyelenggaraan pelayanan publik serta pembangunan mendapatkan alokasi yang relatif kecil maka terjadinya kerusakan infrastruktur berupa prasarana infrastruktur jalan, irigasi, sekolah dan lain lain sebagaimana pada Tabel 4.

Tabel 4. Alokasi Pengeluaran APBD Kabupaten Indramayu Tahun 2006-2007

\begin{tabular}{lrr}
\hline \multicolumn{1}{c}{ Alokasi Bidang } & \multicolumn{1}{c}{2006} & \multicolumn{1}{c}{2007} \\
\hline Pendidikan & $12.110 .000 .000,00$ & $2.834 .000 .000,00$ \\
Kesehatan & $6.250 .000 .000,00$ & $7.112 .000 .000,00$ \\
Pengairan & $5.890 .000 .000,00$ & $6.771 . .000 .000,00$ \\
Transportasi & $5.210 .000 .000,00$ & $30.950 .000 .000,00$ \\
Perikanan & $3.980 .000 .000,00$ & $713.000 .000,00$ \\
Pertanian & $3.430 .000 .000,00$ & $1.188 .000 .000,00$ \\
Air Bersih & $1.510 .000 .000,00$ & $673.000 .000,00$ \\
Lingkungan Hidup & $300.000 .000,00$ & $56.000 .000,00$ \\
\hline
\end{tabular}

Sumber: Sekretariat Daerah Kabupaten Indramayu, 2007

Tabel 4 diatas menggambarkan terdapat orientasi pemihakan terhadap peningkatan kualitas pendidikan dan pelayanan kesehatan, pemihakan ini bertujuan memperbaiki kekeliruan terdahulu yang mengakibatkan Kabupaten Indramayu selalu menjadi daerah tertinggal dalam pemerataan pendidikan. Meskipun demikian kecilnya alokasi anggaran terhadap pengairan, transportasi, pertanian, air bersih dan lingkungan hidup berdampak terhadap kurangnya perbaikan infrastruktur yang berdampak terhadap pengurangan pendapatan masyarakat.

\section{Analisis Faktor-faktor Internal dan Eksternal Daya Saing Investasi Kabupaten Indramayu}

Investasi diperlukan dalam rangka untuk mencapai pertumbuhan dan pembangunan yang baik di suatu daerah. Agar investasi dapat dilakukan secara tepat dan sesuai dengan kondisi yang ada maka diperlukan penyusunan strategi dengan mempertimbangkan faktor-faktor strategis internal maupun eksternal. Setelah mempertimbangkan faktor-faktor tersebut maka diperlukan penyusunan strategi yang komprehensif melalui rumusan prioritas strategi peningkatan investasi.

Komponen analisis SWOT (internal dan eksternal) yang terdiri atas kekuatan, kelemahan, peluang, dan ancaman akan memiliki urutan prioritas sesuai dengan pendapat para responden. Analisis kondisi internal dilakukan dengan mengidentifikasi kekuatan-kekuatan (strengths) dan kelemahan-kelemahan (weaknesses) daya saing investasi di Kabupaten Indramayu. Faktor kekuatan yang teridentifikasi meliputi: (1) memiliki potensi ekonomi sektor pertanian dan migas, (2) memiliki budaya daerah yang kondusif dalam mengembangkan perekonomian, (3) jumlah tenaga kerja, (4) memiliki letak yang strategis dan wilayah yang luas, (5) memiliki dukungan birokrasi yang baik 
untuk mengembangkan perekonomian, (6) memiliki zona industri yang beragam. Selain itu faktor kelemahan yang teridentifikasi meliputi: (1) adanya perda yang bermasalah, (2) kualitas infrastruktur yang masih rendah, (3) kualitas SDM masih rendah, (4) kurangnya promosi terhadap sektor-sektor unggulan dan potensial, (5) rencana pemekaran Kabupaten Indramayu.

Setelah melakukan identifikasi dan evaluasi terhadap faktor-faktor internal selanjutnya dilakukan juga identifikasi faktor-faktor eksternal yang mengidentifikasikan peluang-peluang (opportunities) dan ancaman-ancaman (threats) yang terkait dengan peningkatan investasi Kabupaten Indramayu. Faktor peluang yang teridentifikasi meliputi: (1) rencana pembangunan bendungan Jatigede di Kabupaten Sumedang, (2) proses pengembangan jalur transportasi darat antara Jakarta-Cirebon melalui Indramayu yang meliputi jalur kereta api dan jalan tol, (3) rencana pengembangan pelabuhan Cirebon menjadi Pelabuhan Samudera. Selain itu faktor ancaman yang teridentifikasi meliputi: (1) lambatnya penerbitan Standar Pelayanan Minimum (SPM) oleh pemerintah pusat, (2) dukungan alokasi kredit dan jaminan kredit perbankan dan non perbankan yang masih rendah, (3) persaingan dengan daerah lain.

Setelah melakukan identifikasi terhadap faktor-faktor internal yakni faktor kekuatan dan kelemahan serta identifikasi faktor ekternal yaitu peluang dan ancaman selanjutnya menganalisis dampak silang antar faktor-faktor; internal (kekuatan dan kelemahan) dan ekternal (peluang dan ancaman) sehingga menentukan alternatif pilihan strategi peningkatan investasi di Kabupaten Indramayu.

Tabel 5. Matriks SWOT Strategi Peningkatan Investasi di Kabupaten Indramayu

\begin{tabular}{|c|c|c|}
\hline EKSTERNAL & $\begin{array}{l}\text { KEKUATAN (S) } \\
\text { 1. Potensi ekonomi } \\
\text { 2. Budaya daerah } \\
\text { 3. Jumlah tenaga kerja } \\
\text { 4. Letak strategis dan luas wilayah } \\
\text { 5. Zona industri }\end{array}$ & $\begin{array}{l}\quad \text { KELEMAHAN (W) } \\
\text { 1. Perda bermasalah } \\
\text { 2. Rendahnya kualitas } \\
\text { infrastruktur } \\
\text { 3. Rendahnya kualitas SDM } \\
\text { 4. Kurangnya promosi } \\
\text { 5. Pemekaran Kab. Indramayu }\end{array}$ \\
\hline $\begin{array}{l}\text { PELUANG }(\mathrm{O}) \\
\text { 1. Pembangunan bendungan } \\
\text { Jatigede Sumedang } \\
\text { 2. Pengembangan jalur } \\
\text { transportasi darat Jakarta- } \\
\text { Cirebon } \\
\text { 3. Pengembangan Pelabuhan } \\
\text { Samudera Cirebon }\end{array}$ & $\begin{array}{l}\text { STRATEGI S-O. } \\
\text { 1. Mengembangkan agroindustry } \\
\text { hulu - hilir dengan } \\
\text { memanfaatkan banyaknya } \\
\text { jumlah SDM dan luas lahan } \\
\text { untuk meningkatkan nilai } \\
\text { tambah pertanian } \\
\text { 2. Meningkatkan kerjasama yang } \\
\text { baik antara pemerintah provinsi } \\
\text { dengan pemerintah kabupaten } \\
\text { yang dituangkan dalam suatu } \\
\text { kebijakan Pro Investasi }\end{array}$ & 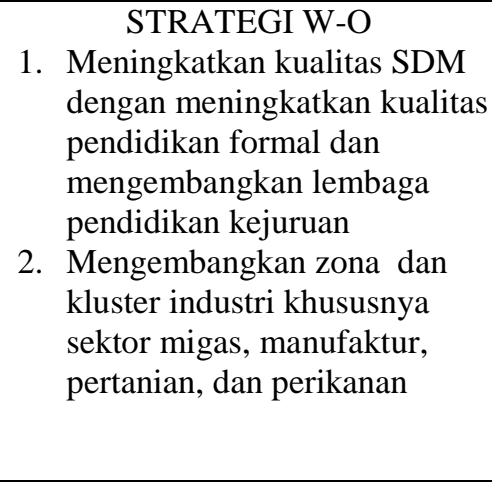 \\
\hline $\begin{array}{l}\text { ANCAMAN (T) } \\
\text { 1. Lambatnya SPM pemerintah } \\
\text { pusat } \\
\text { 2. Alokasi kredit dan suku bunga } \\
\text { perbankan } \\
\text { 3. Persaingan dengan daerah lain }\end{array}$ & $\begin{array}{l}\text { STRATEGI S-T } \\
\text { 1. Menciptakan iklim usaha yang } \\
\text { kondusif dalam menghadapi } \\
\text { persaingan dengan daerah lain } \\
\text { 2. Mengoptimalkan pemanfaatan } \\
\text { potensi ekonomi SDA untuk } \\
\text { menciptakan lapangan kerja }\end{array}$ & $\begin{array}{l}\text { STRATEGI W-T } \\
\text { 1. Mengembangkan kelembagaan } \\
\text { melalui lembaga pelayanan satu } \\
\text { atap } \\
\text { 2. Memperbaiki sarana prasarana } \\
\text { dengan meningkatkan } \\
\text { ketersediaan dana } \\
\text { pembangunan serta } \\
\text { mempercepat pembangunan }\end{array}$ \\
\hline
\end{tabular}

Sumber: Hasil olahan, 2008

Hasil penentuan alternatif (pilihan) strategi bagi peningkatan investasi di Kabupaten Indramayu sebagaimana hasil analisis dari dampak silang antar faktor- faktor internal dan eksternal pada Tabel 5 dapat diuraikan sebagai berikut:

1. Mengembangkan agroindustri huluhilir dengan memanfaatkan banyaknya 
jumlah SDM dan luas lahan untuk meningkatkan nilai tambah pertanian.

2. Meningkatkan kerjasama yang baik antara pemerintah provinsi dengan pemerintah kabupaten yang dituangkan dalam suatu kebijakan Pro Investasi.

3. Meningkatkan kualitas SDM dengan meningkatkan kualitas pendidikan formal dan mengembangkan lembaga pendidikan kejuruan.

4. Mengembangkan zona dan kluster industri sektor migas, manufaktur, pertanian, dan perikanan.

5. Menciptakan iklim usaha yang kondusif dalam menghadapi persaingan dengan daerah lain.

6. Mengoptimalkan pemanfaatan potensi ekonomi SDA untuk menciptakan lapangan kerja.

7. Mengembangkan kelembagaan melalui lembaga pelayanan satu atap.

8. Memperbaiki sarana prasarana dengan meningkatkan ketersediaan dana pembangunan serta mempercepat pembangunan
Dari kedelapan alternatif strategi peningkatan investasi yang dihasilkan berdasarkan analisis SWOT selanjutnya melalui Focus Group Discussion dengan berbagai stakeholder dipilih empat alternatif prioritas strategi peningkatan investasi. Selanjutnya untuk menentukan urutan prioritas strategi apa yang mempunyai nilai strategis dan akan lebih bermanfaat meningkatkan pendapatan rakyat dan penyerapan tenaga kerja ditentukan melalui AHP.

\section{Prioritas Faktor Komponen}

Faktor Kekuatan

Dalam faktor kekuatan terdapat beberapa komponen yang penting untuk diperhatikan dalam peningkatan investasi. Komponen-komponen tersebut yaitu potensi ekonomi, luas wilayah, Jumlah tenaga kerja, letak yang strategis, dukungan birokrasi, dan zona industri. Hasil analisis mengenai prioritas komponen faktor kekuatan dapat dilihat pada Gambar 2.
Potensi

Budaya Daerah

Banyaknya tenaga kerja

Letak dan Luas Wilayah

Dukungan Birokrasi

Zona Industri

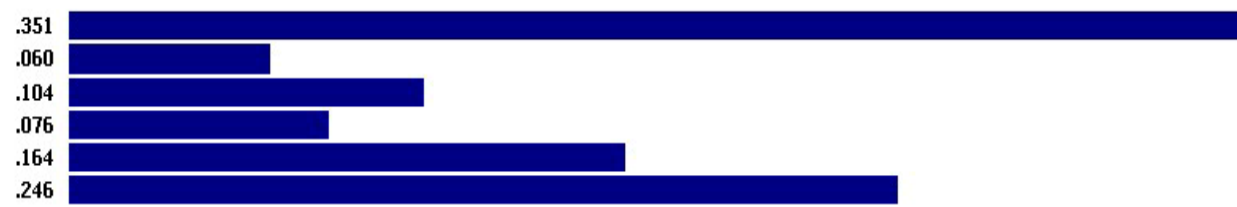

Gambar 2. Prioritas Faktor Komponen Kekuatan Peningkatan Investasi di Kabupaten Indramayu

Pada Gambar 2 menunjukkan bahwa komponen yang memiliki bobot relatif atau memiliki faktor paling dominan adalah potensi ekonomi (0.351) kemudian diikuti oleh zonasi industri (0.246), dukungan birokrasi (0.164), jumlah tenaga kerja (0.104), luas dan letak yang strategis (0.076), dan terakhir yaitu budaya daerah (0.060). Hal ini menunjukkan bahwa hal yang paling utama dalam peningkatan investasi adalah potensi ekonomi. Hal ini dikarenakan potensi ekonomi yang meliputi potensi sumberdaya alam migas dan nonmigas merupakan modal terbesar meningkatkan daya tarik investasi di Kabupaten Indramayu.

Faktor Kelemahan

Dalam faktor kelemahan terdapat beberapa komponen yang penting untuk diperhatikan dalam menghambat peningkatan investasi. Komponenkomponen tersebut yaitu kualitas infrastruktur, kualitas SDM, Peraturan Daerah (perda), promosi dan pemekaran Kabupaten Indramayu. Hasil analisis mengenai prioritas komponen faktor kelemahan dapat dilihat pada Gambar 3. 
Priorities with respect to:

Goal: Strategi Investasi

Xelemahan

Perda Bermasalah
Infras Rendah
SDM Rendah
Kurang Promosi
Pemekaran Kab
Inconsistency = 0.05
with 0 missing judgments.

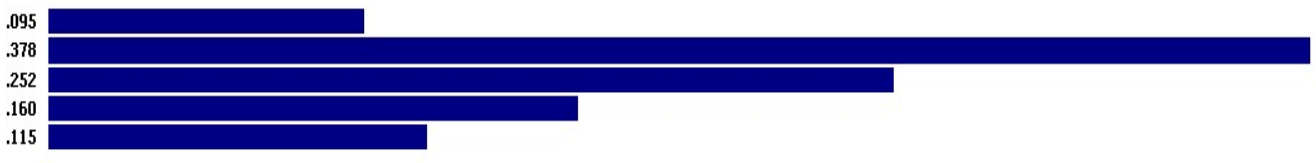

Gambar 3. Prioritas Faktor Komponen Kelemahan Peningkatan Investasi di Kabupaten Indramayu

Pada Gambar 3 menunjukkan bahwa komponen yang memiliki bobot relatif atau memiliki faktor paling dominan adalah kualitas infrastruktur yang masih rendah (0.378) kemudian diikuti oleh kualitas SDM yang rendah (0.252), kurangnya promosi (0.160), pemekaran Kabupaten Indramayu (0.115), dan adanya perda yang bermasalah (0.095). Hal ini menunjukkan bahwa kelemahan yang paling utama dalam peningkatan investasi adalah kualitas infrastruktur yang rendah. Keberadaan infrastruktur yang memadai merupakan prasyarat dalam menggerakan perekonomian masyarakat. Infrastruktur tersebut meliputi seluruh sarana dan prasarana seperti infrastruktur trassportasi, pendidikan, kesehatan, sumberdaya air (PAM, layanan sanitasi, irigasi) dan listrik.

\section{Faktor Peluang}

Dalam faktor peluang terdapat beberapa komponen yang penting untuk diperhatikan dalam peningkatan investasi. Komponen-komponen tersebut yaitu pembangunan bendungan, pengembangan jalur transportasi darat, dan pembangunan Pelabuhan Samudera. Hasil analisis mengenai prioritas komponen faktor peluang dapat dilihat pada Gambar 4.

\footnotetext{
Priorities with respect to:

Goal: Strategi Investasi

>Peluang

Pembangunan Bendungan
Transportasi Darat
Pelabuhan Samudera
Inconsistency $=0.09$
with 0 missing judgments.
}

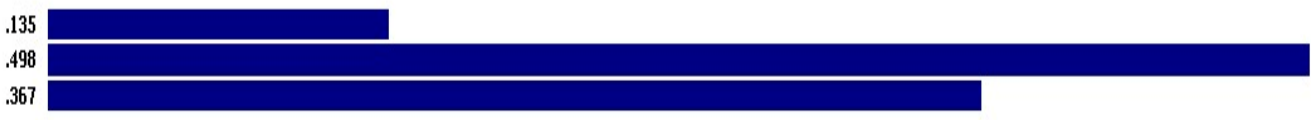

Gambar 4. Prioritas Faktor Komponen Peluang Peningkatan Investasi di Kabupaten Indramayu

Pada Gambar 4 menunjukkan bahwa komponen yang memiliki bobot relatif atau memiliki faktor paling dominan adalah pengembangan jalur transportasi darat (0.498) kemudian diikuti oleh pembangunan Pelabuhan Samudera (0.367), dan terakhir yaitu pembangunan Bendungan Jatigede (0.135). Hal ini menunjukkan bahwa peluang yang paling utama dalam peningkatan investasi adalah pengembangan jalur transportasi darat yang menghubungkan Jakarta dengan Cirebon melalui Indramayu. Jalur transportasi yang akan dikembangkan antara lain: (a) pembangunan double track (rel ganda) kereta api utama lintas provinsi, (b) rencana pembangunan jalan tol Cikampek-Cirebon yang melalui Haurgeulis bagian selatan beserta interchange-nya, (c) pembukaan jalan provinsi Subang-Cikamurang yang menghubungkan Kabupaten Indramayu dengan Kabupaten Subang. Pelaksana dari pembuatan jalan ini adalah BUMN, pemerintah pusat dan provinsi serta sektor swasta. 
Faktor Ancaman

Dalam faktor ancaman terdapat beberapa komponen yang penting untuk diperhatikan dalam peningkatan investasi. Komponen-komponen tersebut yaitu lambatnya penerbitan Standar Pelayanan
Minimal (SPM) oleh pemerintah pusat, rendahnya dukungan perbankan, dan persaingan dengan daerah lain. Hasil analisis mengenai prioritas komponen faktor ancaman dapat dilihat pada Gambar 5.

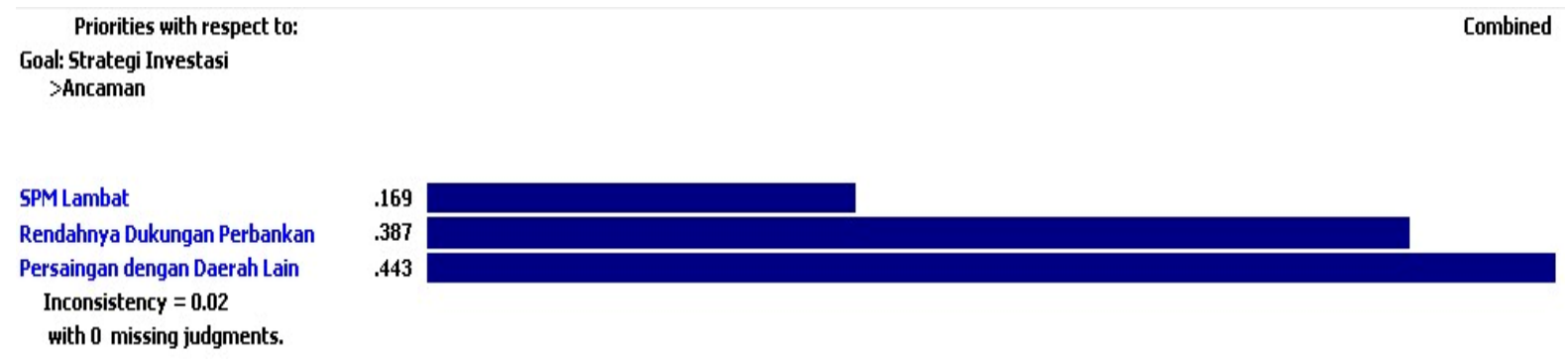

Gambar 5. Prioritas Faktor Komponen Ancaman Peningkatan Investasi di Kabupaten Indramayu

Pada Gambar 5 menunjukkan bahwa komponen yang memiliki bobot relatif atau memiliki faktor paling dominan adalah persaingan dengan daerah lain (0.443) kemudian diikuti oleh rendahnya dukungan perbankan (0.387), dan terakhir yaitu lambatnya penerbitan SPM (0.169). Hal ini menunjukan bahwa ancaman yang paling utama dalam peningkatan investasi Kabupaten Indramayu adalah persaingan dengan daerah lain. Daerah lain yang menjadi ancaman yaitu Purwakarta dan Karawang yang mempunyai zona industri dan mempunyai akses lebih dekat ke Jakarta dan Kabupaten Cirebon lebih dekat ke Pelabuhan Samudra Cirebon. Selain itu persaingan dengan daerah lain karena daerah lain mengusahakan investasi dalam kegiatan yang sejenis, hal ini karena setiap daerah akan melakukan upaya untuk mengoptimalkan potensi sumber daya yang dimiliki dengan cara menarik investor lokal dan asing dalam rangka peningkatan Pendapatan Asli Daerah (PAD) adapun sektor yang sejenis yaitu sektor jasa dan pertanian.

\section{Alternatif \\ Peningkatan \\ Prioritas Investasi Indramayu \\ Strategi Kabupaten}

Sebagaimana yang telah dibahas sebelumnya mengenai identifikasi faktor - faktor daya saing investasi melalui identifikasi kekuatan, kelemahan, peluang dan hambatan (SWOT). Selanjutnya adalah penentuan alternatif prioritas strategi melalui Analitical Hierarchy Process (AHP).

Unit ekonomi (pemerintah dan swasta) memiliki keterbatasan sumberdaya sehingga harus menentukan pilihan berdasarkan prioritas untuk mencapai objek tertentu. Dengan kata lain diperlukan pemilihan prioritas sasaran sesuai dengan kendala yang dihadapi, terutama menyangkut keterbatasan dana dan rentang waktu pelaksanaan investasi, untuk itu diperlukan suatu alternatif strategi yang dapat dilakukan dalam peningkatan investasi di Kabupaten Indramayu sebagaimana hasil identifikasi AHP diantaranya yaitu meningkatkan kualitas sumberdaya manusia (SDM), mengembangkan agroindustri hulu sampai hilir, mengembangkan zona dan kluster industri, dan mengembangkan kelembagaan. Berdasarkan hasil analisis dari pendapat responden ahli maka untuk mencapai tujuan peningkatan investasi maka prioritas alternatif strategi dapat dilihat pada Gambar 6. 
Goal: Strategi Investasi

Oveall llnconsistency $=0.05$

SDM

Agroindustri

Zona dan Kluster

Kelembagaan

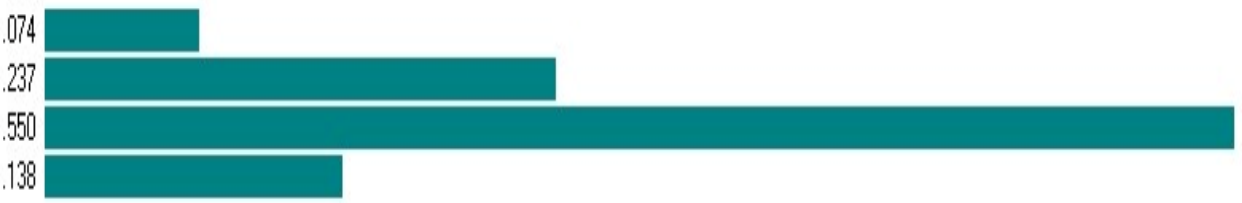

Gambar 6. Prioritas Alternatif Strategi dalam Peningkatan Investasi di Kabupaten Indramayu

\section{KESIMPULAN DAN SARAN}

\section{Kesimpulan}

1. Perkembangan investasi Kabupaten Indramayu selama tahun 2000-2005 menunjukan kecenderungan penurunan, hal ini disebabkan menurunnya daya saing investasi khususnya kerusakan infrastruktur, perda yang tidak pro investasi dan adanya persaingan dengan daerah lain. Meskipun demikian investor tertarik untuk mengolah potensi ekonomi sektor unggulan khususnya sektor pertanian, minyak dan gas bumi serta perikanan.

2. Berdasarkan identifikasi dan analisis faktor daya saing investasi Kabupaten Indramayu dengan menggunakan gabungan SWOT dan AHP menunjukkan bahwa:

a. Prioritas elemen faktor kekuatan yang paling mempengaruhi daya saing investasi Kabupaten Indramayu secara berurutan yaitu potensi ekonomi, zona dan kluster industri, dukungan birokrasi, jumlah tenaga kerja, letak strategis dan luas wilayah, dan budaya daerah.

b. Prioritas elemen faktor kelemahan yang paling mempengaruhi daya saing investasi Kabupaten

Indramayu secara berurutan yaitu kualitas infrastruktur rendah, kualitas SDM yang rendah, kurangnya promosi, pemekaran Kabupaten Indramayu, dan perda yang bermasalah. c. Prioritas elemen faktor peluang yang paling mempengaruhi daya saing investasi Kabupaten Indramayu secara berurutan yaitu pengembangan transportasi darat Jakarta-Cirebon, pembangunan Pelabuhan Samudera Cirebon, dan pembangunan Bendungan Jatigede Sumedang.

d. Prioritas elemen faktor ancaman yang paling mempengaruhi daya saing investasi Kabupaten Indramayu secara berurutan yaitu adanya persaingan dengan daerah lain, rendahnya dukungan perbankan, dan lambatnya penerbitan SPM.

3. Prioritas alternatif strategi dalam peningkatan investasi Kabupaten Indramayu secara berurutan yaitu mengembangkan zona dan kluster industri, mengembangkan agroindustri hulu sampai hilir, mengembangkan kelembagaan, dan meningkatkan kualitas SDM.

\section{Saran}

1. Dalam rangka peningkatan investasi maka harus dilakukan sinergi aktor investasi antara pemerintah, investor swasta dan masyarakat. Dalam sinergi tersebut fungsi pemerintah daerah berperan sebagai fasilitator identifikasi potensi ekonomi unggulan, investor swasta melakukan investasi dengan memanfaatkan potensi ekonomi daerah, dan masyarakat melakukan dukungan terhadap investasi PMA, PMDN, dan Non PMA/PMDN.

2. Untuk dapat merangsang datangnya investasi di Kabupaten Indramayu diperlukan peningkatan daya saing 
investasi daerah melalui optimalisasi zona industri Migas Balongan dan pembuatan zona dan kluster industri Losarang dan Sukra serta peningkatan alokasi anggaran pemerintah daerah dalam perbaikan sarana dan prasarana infrastruktur.

3. Untuk dapat meningkatkan kesejahteraan masyarakat dengan memanfaatkan jumlah tenaga kerja dan potensi ekonomi sektor pertanian dan perikanan maka strategi alternatif investasi kerjasama pemerintah (BUMD Bumi Wiralodra), swasta, dan masyarakat yaitu fokus merealisasikan agricentre. Adapun investasi sektor migas didorong kepada BUMN dan investor swasta.

\section{DAFTAR PUSTAKA}

Arsyad, Lincoln. 1999. Pengantar Perencanaan dan Pembangunan Ekonomi Daerah. Yogyakarta: BPFE.

[Bapeda] Badan Perencanaan Daerah. 2005. Selayang Pandang Indramayu. Bapeda Kabupaten Indramayu.

[Bappenas] Badan Perencanaan Pembangunan Nasional. 2007. Pengembangan Ekonomi Daerah dan Sinergi Kebijakan Investasi Pusat - Daerah. Bappenas Jakarta.

[BKPM] Badan Koordinasi Penanaman Modal. 2007. Undang - Undang Republik Indonesia Nomor 25 Tahun 2007 Tentang Penanaman Modal. BKPM. Jakarta.

Boediono. 1985. Teori Pertumbuhan Ekonomi. Yogyakarta: BPFE.

Boediono, Piter A, Alisyahbana A. \& Effendi N. 2004, Daya Saing Daerah Konsep dan Pengukurannya di Indonesia. Yogyakarta: BPFE.

[BPPMD] Badan Promosi dan Penanaman Modal Daerah Jawa Barat. 2006. Perkembangan Investasi PMDN dan PMA di Jawa Barat. Bandung: Badan Promosi dan Penanaman Modal Daerah Jawa Barat.
[BPS] Badan Pusat Statistik. 2005. Indramayu Dalam Angka 2005. Badan Pusat Statistik Kabupaten Indramayu. 2007.

PDRB Provinsi Jawa Barat Menurut Kabupaten/Kota 20002006. BPS. Jakarta.

[DPPMD] Dinas Perizinan dan Penanaman Modal. 2007. Pedoman Umum Petunjuk Teknis Pelaksanaan Pelayanan Perizinan Terpadu Satu Pintu. Dinas Perizinan dan Penanaman Modal Kabupaten Indramayu.

Kuncoro, Mudradjat. 2004. Otonomi dan Pembangunan Daerah Reformasi, Perenncanaan Strategi dan Peluang. Jakarta: PT Erlangga.

Levine, R dan D. Renelt. 1992. A Sensitivity Analysis of CrossCountry Growth Regretion. The American Economic Review 82 (4): 942-963.

Noor, Henry Faizal. 2005. Manajemen Investasi dan Keuangan. Jakarta: STIA - LAN Press.

[Pemda] Pemerintah Daerah Kabupaten Indramayu. 2006. Rencana Pembangunan Jangka Menengah Daerah (RPJMD) Kabupaten Indramayu 2006 - 2010. Bapeda Kabupaten Indramayu.

Rangkuti, F. 2004. Analisis SWOT. Teknik Membedah Kasus Bisnis. Reorientasi Konsep Perencanaan Strategis untuk menghadapi Abad 21. Jakarta: PT.Gramedia Pustaka Utama.

Saaty, Thomas L. 1993. Pengambilan Keputusan bagi Para Pemimpin. Jakarta: PT. Pustaka Binaman Pressindo.

Sekretariat Daerah Kabupaten Indramayu. 2007. Himpunan Lembaran Daerah Tentang Pajak dan Retribusi. Bagian Hukum Sekretariat Daerah Kabupaten Indramayu.

Sukirno. 1994. Ekonomi Pembangunan. Jakarta: LPFE UI. 